\title{
HbAic, Total IgE, and TNFa as Blood Markers for Long Exposure of Traffic-related Fine Particles: A Study on Mechanics at Vehicle Test Stations
}

\section{Doni Hikmat Ramdhan, Zuly P. Rizky, and Hardy Atmajaya}

Department of Occupational Health and Safety, Faculty of Public Health, Universitas Indonesia, Depok, Indonesia

\section{Abstract}

Particulate matter such as hydrocarbons, sulfur oxides (SOx), and nitrogen oxides (NOx) dominate air pollutants released from vehicle emission and are notorious for their adverse health effects. High concentrations of traffic-related air pollutants in urban areas are sometimes neglected by society despite being harmful to human

Corresponding Author: Doni Hikmat Ramdhan doni@ui.ac.id

Received: 21 January 2018 Accepted: 8 April 2018

Published: 17 May 2018

Publishing services provided by Knowledge

(c) Doni Hikmat Ramdhan et al. This article is distributed under the terms of the commons Attribution License, which permits unrestricted use and redistribution provided that the original author and source are credited.

Selection and Peer-review under the responsibility of the 2nd International Meeting of Public Health 2016 Conference Committee. health. This study aimed to discover the blood markers of traffic-related particulate matter in humans. The study collected traffic-related particulate matter 2.5 (PM2.5) data from 32 mechanics working in vehicle emission test stations in Pulo Gadung and Ujung Menteng, Jakarta. Every measurement was made according to the Environmental Protection Agency Isopropil Alcohol 10A (EPA IP 10 A) method. Blood and urine samples were collected from 43 mechanics as an exposed group and 23 non-exposed workers as a control. Profile lipid, glycated haemoglobin (HbA1c), total Imunoglobin (IgE), calcium, and Tumor Necrosis Factor- $\alpha$ (TNF $\alpha$ ) in blood were measured in all 66 samples. Urinary 1-hydroxypyrene (1-OHP) was detected in 21 exposed group samples using a liquid chromatography fluorescence detector. As a result, the mean concentration of PM2.5 from mechanics was $306.91 \pm 99.19 \mu \mathrm{g} / \mathrm{m}^{3}$. Independent t-test results of the biochemical analysis from blood examination within those groups showed a significant difference in several parameters such as triglyceride $(p=0.005), \operatorname{HbA1c}$ NGSP $(p=0.01), \operatorname{HbA1c~IFFC~}(p=0.01)$, total IgE $(p=0.02)$, calcium ( $p$ $=0.03)$, and TNF $\alpha(p=0.00)$. Total cholesterol and personal PM2.5 exposure showed a moderate correlation with $r=0.355(p=0.046)$. Urinary 1-OHP mean concentration from the exposed group was $21.61 \pm 10 \mu \mathrm{g} / \mathrm{L}$. In conclusion, HbA1c, IgE, and TNF $\alpha$ can be considered as a blood marker for long exposure to PM2.5, while further study is needed to determine the possibility of using 1-OHP as non-invasive method to detect the particulate matter exposure in humans, particularly from traffic-related sources. 


\section{INTRODUCTION}

Particulate matter such as hydrocarbons, sulfur oxides (SOx), and nitrogen oxides (NOx) dominate the air pollutants released from vehicle emissions and are notorious for their adverse health effects. Motor vehicle emissions are one of the largest sources of particulate matter, especially diesel-engined vehicles. Diesel engines that are widely used for the transportation industry have the potential to emit exhaust gas (gas exhaust) which contains a mixture of gas and very small particles that can endanger health. Particulate components of diesel exhaust which include a mixture of black carbon, carbon organic elements, sulfates, metals and trace elements are known as Diesel Particulate Matter [4].

Another study stated that exposure to traffic-related particulate matter is responsible for several adverse health effects such as lung dysfunction, asthma, chronic obstructive pulmonary disease (COPD), arteriosclerosis, and stroke $[3,8]$.

Studies related to the association between particulate exposure and reproductive system dysfunction are still uncommon. Our prior study using male Ficher 344 rats found that nano-sized particle from diesel engine emission was responsible for reproductive dysfunction such as an increase of the testosterone hormone in low $\left(15 \mu \mathrm{g} / \mathrm{m}^{3}\right)$ and middle (36 $\mathrm{\mu g} / \mathrm{m}^{3}$ ) exposure groups [9]. Society sometimes neglects high concentrations of traffic-related air pollutants in urban areas despite being harmful to human health. This study aimed to discover the blood markers of traffic-related particulate matter in humans.

\section{METHODS}

Coarse, fine, and ultrafine particles were collected according to the EPA IP-10A method adapted SKC Inc. using the Sioutas Cascade Impactor, which can divide particulate matter by size. Four $25 \mathrm{~mm}$ and one $37 \mathrm{~mm}$ diameter quartz fiber filters were placed in the impactor and sucked by the Leland Legacy personal pump with a flow rate of 9 L/min. Thirty-four mechanics from both Pulogadung and Ujung Menteng vehicle test stations were selected to use these particulate matter personal exposure apparatus during their work time. The mean concentration of particulate matter was calculated by a gravimetric method using a micro balance, in which all the filters were conditioned in a balanced room for 24 hours before initial and final weighing.

Prodia Laboratories conducted all blood tests. A spectrophotometric method was used for the determination of a lipid profile in blood. HbA1c in blood and 
1-hydroxypyrene (1-OHP) in urine were measured using the high-performance liquid chromatography ion exchange technique. Immunochemiluminescent assay and ortho measured total IgE and calcium levels. Furthermore, immunoturbidimetric and electrochemiluminescence immunoassay (ECLIA) methods were used to determine the concentration of hs-CRP and testosterone. For the last test, nitrate/nitrite colorimetric assay and human TNF immunoassay were selected as methods to calculate the concentration of nitrogen Oxide (NO) and TNF $\alpha$.

All the gathered data would be calculated statistically using an independent t-test that would be applied to exposed and control groups. Correlation between all blood markers and fine particle concentrations would be calculated statistically using simple linear regression and Pearson's correlation test.

\section{RESULTS}

Particulate matter was gathered from 32 respondents in both Pulogadung and Ujung Menteng. Every respondent was asked to use particulate matter sampling apparatus during their work hours for various durations from 6 to 12 hours a day. The mean concentration of fine particle personal exposure for mechanics was $306.91 \pm 99.2$ $\mu \mathrm{g} / \mathrm{m}^{3}$. Fine particles peaked at $480.57 \mu \mathrm{g} / \mathrm{m}^{3}$ and no sample was below $110.7 \mu \mathrm{g} / \mathrm{m}^{3}$.

The mean concentration of the total of LDL and HDL cholesterol did not show any significant differences, while the mean comparison of a triglyceride in the exposed and the control groups showed a significant difference with $p=0.005$. Both HbA1c NGSP and IFFC also showed a significant difference with $p=0.01$ and 0.011 , respectively. Similar to the prior results, calcium and TNF $\alpha$ had significant differences while the other parameters, such as the total IgE, hs-CRP, and NO, had no significant differences.

The urinary 1-OHP mean concentration was calculated from 21 urine sample in the exposed group. The 1-OHP mean concentration for the exposed group was $21.61 \pm 10$ ppb. The minimum and maximum concentrations of all samples were 7.85 and 45.20 , respectively.

\section{DISCUSSION}

The abundant levels of particulate matter in the vehicle emission tests correlated with the work performed there. The vehicle emission test sites in Pulogadung and Ujung Menteng had the same workplace design, where the sites were shaped like a tunnel with one entry and exit door for the vehicle that would be tested. The vehicle would 
TABLE 1: Blood markers mean concentration for exposed and control groups.

\begin{tabular}{|c|c|c|c|}
\hline \multirow[t]{2}{*}{ Parameter } & \multicolumn{2}{|c|}{ Mean concentration } & Unit value \\
\hline & Exposed Group & Control & \\
\hline Total cholesterol & $196.30 \pm 33.14$ & $196.60 \pm 34.40$ & $\mathrm{mg} / \mathrm{dL}$ \\
\hline $\begin{array}{l}\text { Low Density Lipoprotein } \\
\text { (LDL) cholesterol }\end{array}$ & $128.25 \pm 29.39$ & $121.52 \pm 30.23$ & $\mathrm{mg} / \mathrm{dL}$ \\
\hline $\begin{array}{l}\text { High Density Lipoprotein } \\
\text { (HDL) cholesterol }\end{array}$ & $42.79 \pm 7.34$ & $46.87 \pm 9.25$ & $\mathrm{mg} / \mathrm{dL}$ \\
\hline Triglyceride & $190.74 \pm 120.26$ & $123.60 \pm 65.83$ & $\mathrm{mg} / \mathrm{dL}$ \\
\hline Testosterone & $445.04 \pm 152.78$ & & $\mathrm{ng} / \mathrm{dL}$ \\
\hline $\mathrm{HbA} 1 \mathrm{c}(\mathrm{NGSP})^{*}$ & $6.24 \pm 2.11$ & $5.34 \pm 0.37$ & $\%$ of total $\mathrm{Hb}$ \\
\hline $\mathrm{HbA} 1 \mathrm{C}(\mathrm{IFFC})^{\star \star}$ & $44.58 \pm 23.20$ & $34.91 \pm 4.22$ & mmol/mol \\
\hline Total IgE & $473.47 \pm 713.28$ & $163.69 \pm 207.33$ & $\mu / L$ \\
\hline Calcium & $9.06 \pm 0.37$ & $9.30 \pm 0.38$ & $\mathrm{mg} / \mathrm{dL}$ \\
\hline $\begin{array}{l}\text { High-sensitivity C- } \\
\text { reactive protein } \\
\text { (hs-CRP) }\end{array}$ & $3.84 \pm 4.19$ & $2.81 \pm 5.84$ & $\mathrm{mg} / \mathrm{L}$ \\
\hline TNF $\alpha$ & $3.05 \pm 2.51$ & $1.31 \pm 0.70$ & $\mathrm{pg} / \mathrm{ml}$ \\
\hline NO & $4.19 \pm 2.32$ & $3.26 \pm 1.09$ & \\
\hline
\end{tabular}

be checked at several points along the tunnel by mechanics. The particulate matter itself was emitted from vehicle combustion emission, the braking process, and road dust from the vehicle's tires. The majority of tests at the sites were of heavy vehicles using a diesel engine. The mean concentration of fine particles in this study was double those of a previous study conducted at Pulogadung vehicle test stations in 2015 [10].

of all blood markers tested using independent t-tests, several parameters showed significant differences; these were triglyceride $(p=0.005), \operatorname{HbA1C} \operatorname{NGSP}(p=0.01)$, HbA1c IFFC $(p=0.01)$, total IgE $(p=0.02)$, calcium $(p=0.03)$, and TNF $\alpha(p=0.00)$. The individual mean concentration of fine particle exposure and personal total cholesterol levels also showed moderate correlation with $r=0.355(p=0.046)$. This result was in line with a 10-year cohort study of 73,117 subjects and over 600,000 samples from the largest healthcare provider in Southern Israel, which found an association between PM10 exposure and an increase of serum glucose, HbA1C, LDL, and triglyceride [11]. Furthermore, long-term exposure to particulate matter is strongly associated with mortality from particular causes of death such as ischemic heart disease, dysrhythmias, heart failure, and cardiac arrest [7]. The high level of triglyceride in the exposed group might occur due to the heavy metal particles emitted from vehicle exhausts [2]. Significance differences in blood lipid and blood sugar parameters in this study agree 
with a study of the elderly in Taiwan that found long-term exposure of air pollution is associated with changes in blood lipids and blood sugars [1].

1-OHP is a biomarker of polycyclic aromatic hydrocarbon (PAH) exposure [6]. More than 130 studies used 1-OHP as a biomarker of PAH exposure in the workplace [5]. The correlation between 1-OHP in this study was still unclear.

\section{CONCLUSIONS}

HbA1c, total IgE, and TNF $\alpha$ can be considered as blood markers for long exposure to particulate matter 2.5 (PM2.5), while further research is needed to determine the possibility of using urinary $1-\mathrm{OHP}$ as a non-invasive method to detect the particulate matter exposure in humans, particularly from traffic-related sources.

\section{ACKNOWLEDGMENTS}

This study is funded by Directorate of Research and Community Services Universitas Indonesia.

\section{References}

[1] Chuang KJ, Yan YH, Chiu SY, Cheng TJ. 2011. Long-term air pollution exposure and risk factors for cardiovascular diseases among the elderly in Taiwan. Occupational and Environmental Medicine. 68(1): 64-8.

[2] Dalton TP, Kerzee JK, Wang B, Miller M, Dieter MZ, Lorenz JN, Shertzer HG, Nebert DW, Puga A. 2001. Dioxin exposure is an environmental risk factor for ischemic heart disease. Cardiovascular Toxicology. 1(4): 285-98.

[3] Garshick E, Laden F, Hart JE, Rosner B, Smith TJ, Dockery DW, Speizer FE. 2004. Lung cancer in railroad workers exposed to diesel exhaust. Environmental Health Perspectives. 112(15): 1539-43.

[4] Kittelson DB. 1998. Engines and nanoparticles: a review. Journal of Aerosol Science. 29(5): 575-588.

[5] Morgott DA. 2014. Factors and trends affecting the identification of a reliable biomarker for diesel exhaust exposure. Critical Reviews in Environmental Science and Technology. 44(16): 1795-864. 
[6] Mucha AP, Hryhorczuk D, Serdyuk A, Nakonechny J, Zvinchuk A, Erdal S, Caudill M, Scheff P, Lukyanova E, Shkiryak-Nyzhnyk Z, Chislovska N. 2006. Urinary 1hydroxypyrene as a biomarker of PAH exposure in 3-year-old Ukrainian children. Environmental Health Perspectives. 114(4): 603.

[7] Pope CA, Burnett RT, Thurston GD, Thun MJ, Calle EE, Krewski D, Godleski J). 2004. Cardiovascular mortality and long-term exposure to particulate air pollution. Circulation. 109(1): 71-7.

[8] Pope III CA, Dockery DW. 2006. Health effects of fine particulate air pollution: lines that connect. Journal of the Air \& Waste Management Association. 56(6): 709-42.

[9] Ramdhan DH, Ito Y, Yanagiba Y, Yamagishi N, Hayashi Y, Li C, Taneda S, Suzuki AK, Watanabe G, Taya K, Kamijima M. 2009. Nanoparticle-rich diesel exhaust may disrupt testosterone biosynthesis and metabolism via growth hormone. Toxicology Letters. 191(2-3): 103-8.

[10] Rizky ZP, Yolla PB, Ramdhan DH. 2016. Evaluation on mechanics and administrative officers at the motor vehicle testing center at Pulo Gadung, DKI Jakarta. Review of Environmental Health. 5: 2-3.

[11] Yitshak Sade M, Kloog I, Liberty IF, Schwartz J, Novack V. 2016. The association between air pollution exposure and glucose and lipids levels. The Journal of Clinical Endocrinology and Metabolism. 101(6): 2460-7. 